\title{
PENINGKATAN KUALITAS DAN UMUR SIMPAN TELUR ASIN DI INDUSTRI RUMAH TANGGA TELUR ASIN MELALUI INOVASI PROSES PRODUKSI
}

\author{
Setyaningrum Ariviani ${ }^{1}$, Gusti Fauza ${ }^{1}$, Dwi Ishartani ${ }^{1}$ \\ ${ }^{1}$ Program Studi Ilmu Teknologi Pangan, Fakultas Pertanian, Universitas Sebelas Maret
}

setya_ariviani@yahoo.com, atau setyaningrum_ariviani@staff.uns.ac.id,gusti_fauza@uns.ac.id, dishtani@yahoo.com

\begin{abstract}
Abstrak
Industri Rumah Tangga (IRT) Telur Asin memiliki kendala terbatasnya telur itik pangon (semi intensif), sehingga mengganti bahan bakunya dengan menggunakan telur itik kandang (intensif). Produksi telur asin dengan bahan baku telur itik intensif dengan proses yang sama menghasilkan telur asin dengan kualitas warna, tekstur dan rasa yang tidak sebaik penggunaan telur itik semi intensif. Kegiatan pengabdian kepada masyarakat (PKM) ini bertujuan untuk meningkatkan kualitas sensoris telur asin produksi IRT telur asin mitra yang dibuat dengan bahan baku telur itik intensif melalui inovasi proses produksi dengan penggunaan ekstrak daun jati dan pengovenan. Umur simpan dan kualitas mikrobiologis (total mikrobia kontaminan) serta kualitas gizi (proksimat) telur asin inovasi juga ditentukan. Hasil evaluasi kegiatan pengabdian menunjukkan bahwa terjadi peningkatan kualitas sensoris, mikrobiologis dan umur simpan setelah introduksi inovasi proses produksi di IRT telur asin mitra. Penambahan ekstrak daun jati dan pengovenan menghasilkan telur asin dengan warna kuning telur dengan intensitas warna oranye yang lebih tinggi, dan tekstur yang lebih kesat. Umur simpan meningkat dari 4 hari menjadi 10 hari, total cemaran mikrobia pada awal masa simpan dari 8,0 x $10 \mathrm{CFU} / \mathrm{g}$ menjadi $1,1 \mathrm{x} 10 \mathrm{CFU} / \mathrm{g}$, pada akhir masa simpan dari 7,8 x $105 \mathrm{CFU/g}$ menjadi 2,23 x $105 \mathrm{CFU} / \mathrm{g}$. Kadar air, mineral total, lemak, protein dan karbohidrat telur asin inovasi berturut-turut $67,13 \pm 0,65 \% ; 7,09 \pm 0,26 \% \mathrm{db} ; 45,05 \pm 1,52 \% \mathrm{db} ; 40,80 \pm 2,64$ $\% \mathrm{db}$; dan $7,06 \pm 2,02 \% \mathrm{db}$.
\end{abstract}

Kata Kunci : Kualitas, telur asin, inovasi proses, umur simpan

\section{PENDAHULUAN}

Telur merupakan sumber protein hewani dengan kualitas protein terbaik yang ditunjukkan dengan nilai NPU (Net Protein Utilization) mencapai 96,5-97,5. Telur juga merupakan pangan dengan densitas gizi yang baik, kaya vitamin A, selenium, biotin, asam amino esensial dan folat (Ariviani et al., 2017; Cheng et al., 2018). Telur asin merupakan produk olahan telur yang memiliki kadar komponen gizi yang tidak kalah dibanding telur segar (Benjakul dan Kaewmanee, 2017).
Telur asin umumnya dibuat menggunakan telur itik karena menghasilkan telur asin dengan karakteristk yang lebih diinginkan seperti kuning telur yang berwarna oranye, bertekstur masir dan berminyak pada bagian tepi (Kaewmanee et al., $2011^{\text {a }}$ ). Kualitas telur asin selain dipengaruhi oleh umur simpan juga dipengaruhi oleh kualitas sensorisnya antara lain tekstur dan warna kuning dan putih telur. Tekstur kuning telur merupakan faktor utama yang mengatur penerimaan konsumen dan permintaan pasar. Tekstur kuning

$$
\text { Teknologi Tepat Guna }
$$


telur yang masir dan yang lebih berminyak lebih disukai konsumen (Kaewmanee et al., 2009; Kaewmanee et al., 2011 ${ }^{\mathrm{b}}$ ). Tekstur, kenampakan dan rasa putih telur dari telur asin merupakan faktor yang menentukan penerimaan konsumen (Kaewmanee et al., 2011 ${ }^{\mathrm{b}}$ ).

Menurut Sarworini (2002) telur itik dibedakan menjadi dua yaitu telur yang dihasilkan oleh itik yang dipelihara secara semi intensif (pangon) dan intensif (kandang). Sistem pemeliharaan kandang menghasilkan telur dengan jumlah yang lebih banyak, sehingga ketersediaan di pasar lebih melimpah dengan harga yang lebih murah dibandingkan sistem pangon. Namun telur asin yang dihasilkan dari telur itik kandang memiiliki warna kuning telur yang lebih pucat (Akhadiarto, 2010) dan tekstur putih telur yang kurang kesat.

Industri rumah tangga (IRT) telur asin menghadapi kendala sulitnya memperoleh dan mahalnya bahan baku telur itik pangon. Penggantian bahan baku dengan telur itik kandang menghasilkan telur asin dengan warna kuning telur lebih pucat, tekstur yang kurang kesat dan rasa yang tidak sebaik penggunaan telur itik pangon.

Penggunaan ekstrak daun jati dan pengovenan terbukti mampu menghasilkan telur asin rendah sodium dengan bahan baku telur itik kandang yang memiliki kualitas sensoris signifikan lebih tinggi dibanding telur asin konvensional yang dibuat dengan telur itik pangon (Ariviani et al., 2018). Penggunaan ekstrak daun jati terbukti mampu meningkatkan kualitas warna kuning telur ayam asin (Syahidah, 2014), meningkatkan kualitas mikrobiologis sosis (Pahlevi, 2011) maupun telur ayam asin (Syahidah, 2014). Menurut Nurhidayat et al. (2013) pengovenan mampu meningkatkan kemasiran telur asin. Pengovenan juga mampu memperpanjang umur simpan telur asin dan menurunkan kadar airnya (Novia et al., 2012) sehingga berkontribusi pada tekstur yang lebih kesat.

Kegiatan pengabdian yang dilakukan bertujuan untuk meningkatkan kualitas sensoris, mikrobilogis dan umur simpan telur asin produksi IRT telur asin mitra yang dibuat dengan bahan baku telur itik kandang melalui inovasi proses produksi, yaitu penggunaan ekstrak daun jati dan pengovenan. Keberhasilan kegiatan pengabdian dievaluasi dengan pengukuran kualitas sensoris, mikrobiologis, umur simpan, kualitas gizi dari telur asin yang dibuat dengan telur itik pangon tanpa inovasi proses dan telur asin dari telur itik kandang yang dibuat dengan inovasi proses produksi.

\section{METODE}

Tujuan kegiatan pengabdian dicapai dengan beberapa tahapan yaitu (1) penyuluhan dan pelatihan pembuatan telur asin dari bahan telur itik kandang dengan inovasi proses produksi yaitu penggunaan ekstrak daun jati dan pengovenan, (2) Analisis kualitas sensoris, umur simpan, kualitas mikrobiologis dan kualitas gizi (proksimat) telur asin dengan dan tanpa inovasi proses produksi. Kualitas sensoris dilakukan dengan uji pembedaan metode Multiple Comparison Test (Meilgaard et al., 1999) menggunakan 30 orang panelis. Kualitas mikrobiologis diukur dengan pengukuran total plate count (TPC) dengan metode pour plate (AOAC 990.12, 1990). Umur simpan ditentukan berdasarkan kemunduran mutu sensorisnya selama penyimpanan. Kualitas gizi ditentukan dengan pengukuran kadar air (AOAC 985.14, 2005), lemak (AOAC 960.39, 2005), protein (AOAC 992.15, 2005), mineral total (AOAC 942.05, 2005), dan karbohidrat (by difference) (AOAC 986.25, 2005).

\section{HASIL DAN PEMBAHASAN}

\section{Penyuluhan dan pelatihan pembuatan telur asin dari bahan telur itik kandang dengan inovasi proses produksi}

Inovasi teknologi produksi telur asin dengan penggunaan bahan baku telur itik kandang untuk mengatasi keterbatasan ketersediaan dan mahalnya telur itik pangon dilakukan dengan proses yang sama dengan proses produksi telur asin yang dilakukan oleh mitra IRT telur asin, dengan inovasi penggunaan ekstra daun jati dan penambahan tahapan proses pengovenan selama 30 menit pada akhir proses produksi. Penggunaan ekstrak daun jati untuk mengatasi masalah warna kuning telur dari telur bebek ternak yang berwarna kuning pucat. Pengovenan bertujuan untuk mengatasi masalah tekstur telur bebek ternak yang kurang kesat. Introduksi produksi telur asin inovasi dengan penggunaan bahan baku telur itik ternak dan telur asin yang dihasilkan dibanding penggunaan telur bebek pangon yang

$$
\text { Teknologi Tepat Guna }
$$


diolah secara konvensional (tanpa inovasi proses) disajikan pada Gambar 1.

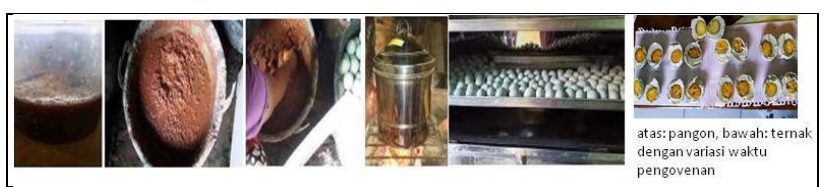

Gambar 1. Introduksi produksi telur asin inovasi dengan bahan baku telur itik kandang dan kualitasnya dibandingkan telur asin konvensional menggunakan telur itik pangon

\section{Kualitas sensoris telur asin}

Kualitas sensoris yang ditentukan meliputi kualitas warna kuning telur, warna putih telur, aroma, rasa, tekstur dan overall. Skor kualitas ditentukan dengan membandingkannya dengan referen (R) yang merupakan telur asin yang dibuat dari telur itik pangon tanpa inovasi proses. Tabel 1 menunjukkan kualitas sensoris telur asin dengan dan tanpa inovasi proses produksi.

Tabel 1. Kualitas Sensoris telur asin dengan dengan dan tanpa inovasi proses

\begin{tabular}{lllllll}
\hline Telur asin & \multicolumn{5}{c}{ Skor Kualitas Sensoris $\left(^{*}\right)$} \\
\cline { 2 - 7 } $\begin{array}{l}\text { (bahan telur } \\
\text { itik, proses) }\end{array}$ & $\begin{array}{l}\text { Warna } \\
\text { putih telur }\end{array}$ & $\begin{array}{l}\text { Warna } \\
\text { kuning telur }\end{array}$ & Aroma & Tekstur & Rasa & Overall \\
\hline $\begin{array}{l}\text { Pangon, tanpa } \\
\text { inovasi proses }\end{array}$ & $5,90 \pm 0,30^{\mathrm{a}}$ & $5,93 \pm 0,25^{\mathrm{a}}$ & $5,10 \pm 0,40^{\mathrm{b}}$ & $5,93 \pm 0,64^{\mathrm{a}}$ & $4,97 \pm 0,32^{\mathrm{b}}$ & $4,97 \pm 0,32^{\mathrm{b}}$ \\
$\begin{array}{l}\text { Kandang, dengan } \\
\text { inovasi proses }\end{array}$ & $6,00 \pm 0,45^{\mathrm{a}}$ & $6,00 \pm 0,45^{\mathrm{a}}$ & $5,77 \pm 0,43^{\mathrm{a}}$ & $5,97 \pm 0,55^{\mathrm{a}}$ & $5,60 \pm 0,49^{\mathrm{a}}$ & $5,73 \pm 0,69^{\mathrm{a}}$ \\
\hline
\end{tabular}

Ket: superscript yang berbeda pada kolom yang sama menunjukkan beda nyata ( $\mathrm{p}<0,05)$. (*) Skor $4=$ agak lebih buruk dari R, Skor 5= sama dengan R, Skor 6= agak baik dari R. R merupakan telur asin dari telur itik pangon tanpa inovasi proses.

Data pada Tabel 1 mengindikasikan bahwa inovasi proses dengan penggunaan ekstrak daun jati dan pengovenan mampu menutupi kekurangan telur itik kandang, sehingga menghasilkan telur asin dengan kualitas warna kuning telur, putih telur, dan tekstur yang tidak berbeda signifikan dengan telur asin dari telur itik pangon. Penggunaan ekstrak daun jati dan pengovenan juga terbukti mampu memperbaiki kualitas aroma, rasa dan keseluruhan telur asin dari telur itik kandang sehingga meperlihatkan skor kualitas yang signifikan lebih tinggi pada ketiga atribut tersebut dibanding telur itik pangon yang dibuat tanpa inovasi proses. Hasil ini sejalan dengan Ariviani et al. (2018) yang melaporkan bahwa penggunaan ekstrak daun jati dan pengovenan meningkatkan kualitas sensoris telur asin rendah sodium. Syahidah (2014), Ariviani et al.
(2010) menunjukkan bahwa penggunaan ekstrak daun jati mampu memperbaiki kualitas rasa, dan overall telur asin rendah sodium yang menurun akibat penggunaan garam KCl. Sari (2013) menyebutkan bahwa tekstur dan citarasa telur asin dapat diperbaiki dengan cara pengovenan.

\section{Umur simpan dan kualitas mikrobiologis telur asin}

Berdasarkan hasil uji kemunduran mutu sensoris yang dilakukan selama periode penyimpanan (data tidak ditampilkan) diketahui bahwa telur asin yang dibuat dengan telur itik pangon, tanpa inovasi proses memiliki umur simpan 4 hari. Telur asin dari telur itik kandang yang dibuat dengan inovasi proses memiliki umur simpan 10 hari. Peranan ekstrak daun jati dalam memperpanjang umur simpan telur asin terkait komponen penyusunnya yang mampu berperan sebagai antimikrobia. Aplikasi ekstrak daun jati terbukti mampu menghambat kerusakan mkrobiologis sosis (Pahlevi, 2011) dan telur ayam asin rendah sodium (Syahidah, 2014) hal ini terkait dengan komponen flavonoid dan fenolik yang terdapat dalam ekstrak daun jati yang dapat berperan sebagai antimikrobia. Peranan pengovenan dalam meningkatkan umur simpan terkait dengan penguapan air dari telur asin selama pengovenan yang berdampak pada penurunan jumlah air bebasnya. Air bebas merupakan air yang dapat digunakan untuk pertumbuhan mikroba, reaksi kimia maupun enzimatis yang menyebabkan dekompsisi bahan pangan dan berdampak pada degradasi mutunya (Nielsen, 2010). Novia et al. (2012) menunjukkan bahwa pemasakan telur asin yang telah diberi perlakuan oven mampu mempertahankan umur simpan lebih lama dibandingkan telur asin yang hanya diberi perlakuan perebusan.

Kualitas mmikrobologis telur asin ditentukan dengan mengukur jumlah total mikrobia kontaminan pada awal dan akhir umur simpan. Datanya disajikan pada Tabel 2. Hasilnya memperlihatkan bahwa inovasi proses menghasilkan jumlah total mikrobia kontaminan yang lebih rendah. Hal ini terkait dengan peranan pengovenan dalam menurunkan jumlah air bebas dan senyawa dalam ekstrak daun jati yang memiliki aktivitas antimikrobia.

$$
\text { Teknologi Tepat Guna }
$$


Tabel 2. Kualitas mikrobologis telur asin di awal dan akhir umur simpan

\begin{tabular}{lll}
\hline \begin{tabular}{l} 
Telur asin $\begin{array}{l}\text { (bahan telur itik, } \\
\text { proses })\end{array}$ \\
\cline { 2 - 3 }
\end{tabular} & \multicolumn{2}{l}{$\begin{array}{l}\text { Total mikrobia kontaminan } \\
\text { (CFU/g) }\end{array}$} \\
\cline { 2 - 3 } & Awal & $\begin{array}{l}\text { Akhir umur } \\
\text { simpan }\end{array}$ \\
\hline $\begin{array}{l}\text { Pangon, tanpa inovasi } \\
\text { proses }\end{array}$ & $4.95 \times 10^{2}$ & $7.8 \times 10^{5}$ \\
$\begin{array}{l}\text { Kandang, dengan } \\
\text { inovasi proses }\end{array}$ & $3.85 \times 10^{2}$ & $2.23 \times 10^{5}$ \\
\hline
\end{tabular}

\section{Kualitas gizi telur asin}

Konsumsi telur umumnya ditujukan untuk mendapatkan komponen gizi. Oleh karena itu evaluasi kualitas gizi juga dilakukan pada telur asin yang dibuat dengan telur itik kandang dengan inovasi proses dibandiingkan kualitas gizi telur asin dari telur itik pangon yang dibuat tanpa inovasi proses. Kualitas gizi ditentukan dengan pengukuran kadar air, lemak, protein, mineral total dan karbohidrat. Datanya disajikan pada Tabel 3.

\begin{tabular}{|c|c|c|}
\hline Kualitas gizi & $\begin{array}{lr}\text { Telur } & \text { asin dari } \\
\text { telur } & \text { pangon, } \\
\text { tanpa } & \text { inovasi } \\
\text { proses } & \end{array}$ & $\begin{array}{l}\text { Telur asin dari } \\
\text { telur kandang, } \\
\text { dengan inovasi } \\
\text { proses }\end{array}$ \\
\hline Kadar Air (\%wb) & $68,14 \pm 0,25^{\mathrm{a}}$ & $67,13 \pm 0,65^{b}$ \\
\hline $\begin{array}{l}\text { Kadar Mineral } \\
\text { Total }(\% \mathrm{db})\end{array}$ & $10,35 \pm 1,50^{\mathrm{a}}$ & $7,09 \pm 0,26^{\mathrm{b}}$ \\
\hline $\begin{array}{l}\text { Kadar Lemak } \\
(\% \mathrm{db})\end{array}$ & $42,15 \pm 1,30^{\mathrm{b}}$ & $45,05 \pm 1,52^{\mathrm{a}}$ \\
\hline $\begin{array}{l}\text { Kadar Protein } \\
(\% \mathrm{db})\end{array}$ & $32,86 \pm 0,94^{b}$ & $40,80 \pm 2,64^{\mathrm{a}}$ \\
\hline $\begin{array}{l}\text { Karbohidrat } \\
(\% \mathrm{db})\end{array}$ & $14,65 \pm 1,90^{\mathrm{a}}$ & $7,06 \pm 2,02^{\mathrm{b}}$ \\
\hline
\end{tabular}

Superscript yang berbeda pada baris yang sama menunjukkan berbeda nyata $(\mathrm{p}<0,05)$

Berdasarkan data pada Tabel 3 diketahui bahwa pengovenan berdampak pada kadar air dan kadar mineral toatal yang lebih rendah. Hal ini dikarenakan selama pengovenan terjadi penguapan air dan keluarnya garam ke permukaan kulit telur asin. Perbedaan kadar lemak, proten dan karbohidrat terkait dengan perbedaan jenis pemeliharaan kedua bahan baku telur itik yang digunakan yang tentu saja berpengaruh terhadap asupan pakan yang berbeda. Perbedaan asupan pakan berpengaruh terhadap komponen gizi telur yang dihasilkan (Ketaren dan Prasetyo, 2002; Fitasari et al., 2013). Hasil evaluasi kualitas gizi ini menunjukkan bahwa pengembangan telur asin dari telur itik kandang dengan penambahan ekstrak daun jati dan pengovenan ini tidak mengurangi potensi konsumsi telur sebagai sumber pangan kaya gizi.

\section{KESIMPULAN}

Permasalahan yang diihadapi IRT telur asin mitra terkait terbatasnya ketersediaan dan mahalnya bahan baku telur itik pangon dapat diatasi dengan menggunakan bahan baku telur itik kandang yang melimpah dan lebih murah harganya melalui inovasi proses produksi. Hal ini didukung oleh data evaluasi mutu yang menunjukkan bahwa telur asin yang dibuat dari telur itik kandang dengan inovasi proses menggunakan ekstrak daun jati dan pengovenan memiliki kualitas sensoris, umur simpan, kualitas mikrobioologis yang lebih baik dibanding telur asin dari telur itik pangon. Ditinjau dari kualitas gizinya, telur asin dari telur itk kandang ini memiliki kualitas gizi yang lebih baik, ditunjukkan dengan kadar lemak dan protein yang signifikan lebih tinggi dan kadar karbohidrat yang lebih rendah.

\section{UCAPAN TERIMAKASIH}

Ucapan terimakasih kepada Kemenristek DIKTI atas pembiayaan kegiatan pengabdian melalui hibah Program Kemitraan Masyarakat (PKM) tahun 2019 dengan nomor kontrak 720/UNS.27.21/PMM/2019.

\section{REFERENSI}

Akhadiarto. (2010). Pengaruh Pemberian Pakan Itik dengan Limbah Udang dan Limbah Kulit Kacang Kedelai yang Diberi Probiotik Terhadap Produksi dan Warna Kuning Telur. Jurnal Teknik Lingkungan, 11(2): 255-263. 
AOAC. (1990). Official method of analysis of the association of official analytical chemist $15^{\text {th }}$ Edition. Washington, DC: Association Official Analytical Chemists.

AOAC. (2005). Official method of analysis of the association of official analytical chemist $18^{\text {th }}$ Edition. Gaithersburg, Maryland, USA : Asociation of Official Analytical Chemist.

Ariviani S, Fauza G, Dewi DK. (2018). Potensi Telur Itik Intensif untuk Produksi Telur Asin Rendah Sodium. Prosiding Seminar Nasional Dalam Rangka Dies Natalis Uns Ke 42 Tahun 2018, 2(1): F72-F80.

Ariviani S, Affandi DR, Amanto BS. (2010). Pengembangan Telur Asin yang Aman bagi Penderita Hipertensi dan Kaya Antioksidan: Kualitas Gizi dan Sensoris. Laporan Penelitian. Program penelitian dana DIPA BLU Fakultas Pertanian Universitas Sebelas Maret.

Ariviani S, Fitriasih NH, Ishartani D. (2017). Development of Low Sodium Salted Eggs and Its Antioxidant Potential. Indonesian Journal of Nutrition and Dietetics, 5(2): 51 - 59. doi: http://dx.doi.org/10.21927/ijnd.2017.5(2).51-59.

Benjakul S \& Kaewmanee T. (2017). Sodium Chloride Preservation in Duck Eggs. In: Patricia Hester, editors. Egg Innovation and Strategies for Improvement, Oxford: Academic Press. p. 415-426.

Cheng S, Zhang T, Wang X, Song Y, Wang H, Wanga H, Yang P, Mingqian Tan M. (2018). Influence of Salting Processes on Water and Lipid Dynamics, Physicochemical and Microstructure of Duck Egg. LWT - Food Science and Technology, 95: 143-149. doi: 10.1016/j.lwt.2018.04.074

Fitasari E, Kristoforus R, Nadia N. (2013). Penggunaan Kadar Protein Berbeda pada Ayam Kampung terhadap Penampilan Produksi dan Kecernaan Protein. Jurnal Ilmu-Ilmu Peternakan, 26(2): 73-83.

Kaewmanee T, Benjakul S, Visessanguan W. (2009). Effect of Salting Processes on Chemical Composition, Textural Properties and Microstructure of Duck Egg. Journal of food science and Agriculture, 89(4): 625-633. DOI: $10.1002 /$ jsfa.349
Kaewmanee T, Benjakul S, Visessanguan W. (2011a). Effect of $\mathrm{NaCl}$ on Thermal Aggregation of Egg White Proteins from Duck Egg. Food Chemistry 125: 706-712. doi:10.1016/j.foodchem.2010.09.072

Kaewmanee T, Benjakul S, Visessanguan W. $\left(2011^{b}\right)$. Effects of Salting Processes and Time on the Chemical Composition, Textural Properties, and Microstructure of Cooked Duck Egg. Journal of Food Science, 76(2): S139-S147. doi: 10.1111/j.1750-3841.2010.01975.x

Ketaren, Pius P. Dan L. H. Prasetyo. 2002. Pengaruh Pemberian Pakan Terbatas terhadap Produktivitas Itik Silang Mojosari X Alabio (MA): Masa Bertelur Fase Pertama Umur 20-43 Minggu. JITV, 7(1): 38-45.

Meilgaard M, Civille GV dan Carr BT. 1999. Sensory Evaluation Techniques. Third edition, Boca Raton: CRC Press.

Nielsen SS. 2010. Food Analysis, Food Science Texts Series. Fourth edition. USA: Springer Science+Business Media, LLC. DOI 10.1007/978-1-4419-1478-1_6

Novia D, Melia S, Ayuza NZ. (2012). Studi Suhu Pengovenan terhadap Umur Simpan Telur Asin. Jurnal Peternakan Indonesia, 4(1): 263169.

Nurhidayat Y, Sumarmono J, Wasito S. (2013). Kadar Air, Kemasiran dan Tekstur Telur Asin Ayam Niaga yang Dimasak dengan Cara Berbeda. Jurnal Ilmiah Peternakan, 1(3): 813820.

Pahlevi YR. (2011). Aplikasi Edible Coating Chitosan-Ekstrak Daun Jati pada Sosis Daging Sapi untuk Menghambat Kerusakan Mikrobiologis dan Oksidatif. Skripsi. Fakultas Pertanian Universitas Sebelas Maret. Surakarta.

Sari FRE. 2013. Karakteristik Kimia dan Mikrobiologi serta Organoleptik Telur Asin dengan Lama Pengovenan yang Berbeda selama Penyimpanan. Skripsi. Institut Pertanian Bogor. Bogor. 
Sarworini. 2002. Pemeliharaan Ternak Itik Secara Intensif. Balai Pengkajian Teknologi Pertanian (BPTP) Sumatera Selatan. Palembang.

Syahidah AA. (2014). Aplikasi Kulit Buah Naga Merah (Hylocereus polyrhizus) dan Daun Jati (Tectona grandis L. F., Verbenaceae) pada Teknologi Produksi Telur Ayam Asin Rendah Sodium: Sensori, Mikrobiologis, dan Antioksidan. Skripsi. Fakultas Pertanian, Universitas Sebelas Maret. Surakarta. 